\title{
MOMENTUM 21 JUNI 2018 (MENGENANG BUNG KARNO, HUT HAMDAN ZOELVA DAN PRESIDEN JOKOWI, PERNIKAHAN KERABAT DAN SAHABAT, SERTA HARI KRIDA PERTANIAN)
}

\author{
Oleh: M. Jamil ${ }^{1}$
}

Suasana haru biru mencekam, itulah yang dirasakan oleh warga Indonesia saat meninggalnya Presiden Soekarno di Jakarta, 21 Juni 1970 pada umur 69 tahun. Hari ini, tanggal 21 Juni yang juga hari meninggalnya sang putra fajar bung Karno. Jasa-jasanya untuk bangsa ini tidak akan bisa terlupakan sepanjang masa. Lahumul fatihah. Semoga arwahnya ditempatkan pada tempat yang istimewa, dan juga semoga jerih payah perjuangan bung Karno mampu diteruskan oleh pemuda dan kita semua sebagai penerus bangsa. Aamiin.

Topik berbeda. Kita tahu bersama bahwasannya Indonesia merupakan salah satu negara demokrasi yang menerapkan teori trias politika. Teori ini untuk pertama kali dikemukakan oleh John Locke (1632-1704) dan Montesquieu (16891755). Trias Politika yang kini banyak diterapkan, salahsatunya di Indonesia, adalah pemisahan kekuasaan kepada 3 lembaga berbeda: Legislatif, Eksekutif, dan Yudikatif.

Berbicara Yudikatif, di Indonesia kita kenal salahsatunya Mahkamah Konstitusi (MK). Obrolin seputar MK, pasti kita sebagai bangsa Indonesia tidak bisa menafikkan kontribusi besar yang pernah dilakukan oleh Ketua MK RI keempat 2013-2015 asal Bima NTB yakni Dr. Hamdan Zoelva, S.H., M.H., hari ini, 21 Juni adalah hari bahagianya, karena pada hari ini adalah Hari Ulang

1 Ketua Umum Pusat Studi Mahasiswa Pascasarjana (PUSMAJA) Mbojo-Yogyakarta Periode 2015-2017 | | Ketua II Bagian Eksternal Dewan Pimpinan Cabang Perhimpunan Mahasiswa Hukum Indonesia Daerah Istimewa Yogyakarta (DPC PERMAHI DIY) Periode 20122014 | Email: jamilncera@gmail.com | FB/Youtube/IG/Twitter: @MJAMILSH | Website: http://www.mjamil.my.id. 
"Momentum 21 Juni 2018 (Mengenang Bung Karno, HUT Hamdan Zoelva dan Presiden Jokowi, Pernikahan Kerabat dan Sahabat, serta Hari Krida Pertanian)"

tahunnya. Selamat Ulang Tahun buat pak Dr. Hamdan Zoelva, S.H., M.H., semoga sehat selalu dan terus semangat berkontribusi untuk bangsa ini. Aamiin.

Usai obrolin Yudikatif. Kita kembali ke Eksekutif. Ranah Eksekutif, sederhananya kita pahami yakni tupoksinya Presiden, Wakil Presiden dan para Menterinya. Obrolin seputar tanggal 21 Juni, ternyata hari ini juga merupakan hari ulang tahun Presiden Joko Widodo. Terlepas dari pro dan kontra dari kontribusi yang telah dilakukan presiden Jokowi, seorang Presiden merupakan salahsatu roh utama dari sebuah negara. Jokowi di pilih secara konstitusi. Jadi sebagai warga Indonesia, sepatutnya bahu membahu, sama-sama berkontribusi dan juga mendukung kontribusi positif yang dipersembahkan pemerintah. Apabila ada kekeliruan dalam menjalankan pemerintahan ini, juga perlu kita ingatkan bersama.

Terkait taat dan perlunya mendukung pemerintah, Allah Ta'ala berfirman yang artinya: "Hai orang-orang yang beriman, taatilah Allah dan taatilah RasulNya, dan ulil amri (baca: pemimpin) di antara kamu. ....”. (QS. An-Nisa' ayat 59). Selain itu, juga telah di anjurkan dalam hadist, sebagaimana Rasulullah shallallahu alaihi wa sallam bersabda yang artinya: "Mendengar (mematuhi) dan menaati (pemerintah) adalah suatu kewajiban, selama tidak diperintahkan dengan kemaksiatan. ....." (HR. Bukhari: 2738, Muslim: 3423)

Hal yang lain, entah layak atau tidaknya Presiden Jokowi melanjutkan estafet kepemimpinannya, biarlah seluruh rakyat Indonesia menentukannya sendiri pada tahun 2019 nanti. Selamat Ulang Tahun buat Presiden Joko Widodo, mudahan sehat terus dan tetap selalu tegar dalam memimpin bangsa ini sampai amanah rakyat bersandar secara konstitusi di punggungmu. Aamiin. Semoga jajaran Legislatif, Eksekutif, dan Yudikatif juga terus harmonis dalam menjaga keutuhan bangsa ini. Aamiin.

Oh iya yach, tahun ini, karena sesuatu dan lain hal yang perlu dituntaskan, jadi saya tidak pulang kampung menikmati liburan ramadhan bersama sanak saudara. Oh iya yach, mengingat-ingat lagi tanggal 21 Juni, saya punya sepupu, Syamsil, S.Pd. namanya. Syamsil baru saja usai melangsungkan akad nikahnya kemarin pada tanggal 20 Juni 2018, hari ini tanggal 21 Juni 2018 sedang merayakan resepsi pernikahannya di lapangan Desa Diha, Kecamatan 
"Momentum 21 Juni 2018 (Mengenang Bung Karno, HUT Hamdan Zoelva dan Presiden Jokowi, Pernikahan Kerabat dan Sahabat, serta Hari Krida Pertanian)"

Belo, Bima, NTB. Saya sangat bahagia mendengar pernikahanmu bro, walau sedikit agak tidak enak juga dalam hati karena tidak bisa menghadiri momen bahagiamu. Selamat berbahagia saudaraku, semoga keberkahan selalu menyertai pernikahanmu. Aamiin.

Berbicara momentum bahagia dengan hari pernikahan, pada tanggal 21 Juni tahun 2018 ini juga saya melewati hari bahagia serepsi pernikahan temanteman saya, yakni saudara Samrin yang melangsungkan pernikahannya di Kota Bima, NTB. Di tempat yang berbeda juga ada pernikahan teman saya Munazar yang berlangsung di Sila Kabupaten Bima. Maafkan saya karna tidak bisa melihat langsung momentum terindah kalian. Walau demikian, do'a terindah teruntuk pernikahan kalian, semoga selalu bahagia dengan dambaan hati kalian. Aamiin.

Kembali lagi kita melirik secara nasional. Kisaran bulan Juni-Juni, secara nasional memasuki masa panen raya, kita patut berbangga dan acungin jempol pada para petani-petani yang masih setia di garis perjuangan merawat dan memelihara tanaman serta budidayanya. Sebagai salahsatu penghormatan nasional, maka hari ini, 21 Juni diperingati dengan Hari Krida Pertanian. Selamat Hari Krida Pertanian untuk petani Indonesia. Semoga para petani di seluruh Indonesia tahun ini mengalami panen raya yang berlimpah ruah dan hasil panennya mendapatkan keberkahan. Aamiin.

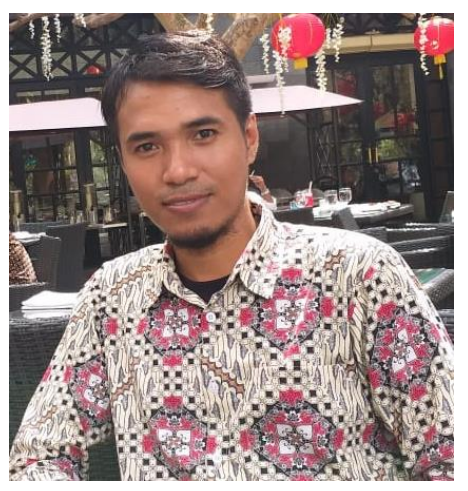

Penulis: M. Jamil, S.H.

Ketua Umum Pusat Studi Mahasiswa Pascasarjana (PUSMAJA) Mbojo-Yogyakarta Periode 2015-2017 | Ketua II Bagian Eksternal Dewan Pimpinan Cabang Perhimpunan Mahasiswa Hukum Indonesia Daerah Istimewa Yogyakarta (DPC PERMAHI DIY) Periode 2012-2014. 
"Momentum 21 Juni 2018 (Mengenang Bung Karno, HUT Hamdan Zoelva dan Presiden Jokowi, Pernikahan Kerabat dan Sahabat, serta Hari Krida Pertanian)"

\section{Ful Sumber Tulisan:}

M. Jamil, "Momentum 21 Juni 2018 (Mengenang Bung Karno, HUT Hamdan Zoelva dan Presiden Jokowi, Pernikahan Kerabat dan Sahabat, serta Hari Krida Pertanian)", dimuat di https://www.pewarta-news.com/2018/06/momentum-21juni-2018-mengenang-bung.html, pada 22 Juni 2018. 